\title{
What should the Government do to Stop Epidemic of Smoking among Teenagers in Indonesia?
}

\author{
Harsman Tandilittin ${ }^{1}$ \\ ${ }^{1}$ Samarinda State Polytechnics, Indonesia \\ Correspondence: Harsman Tandilittin, Samarinda State Polytechnics, Indonesia. E-mail: harsmana@yahoo.com
}

Received: September 2, 2015 Accepted: September 24, $2015 \quad$ Online Published: February 29, 2015

doi:10.5539/ach.v8n1p140

URL: http://dx.doi.org/10.5539/ach.v8n1p140

\begin{abstract}
Smoking epidemic has occurred among the Indonesian adolescents, as the nearly six out of ten the youth of ages 13 to 15 years smoke daily. In fact, Indonesia has also been known as "the country of smoking baby", as some family smokers have deliberately introduced the way of smoking to their toddlers. In Indonesia, the most new smokers has been ensnared by the tobacco industry, as they started to smoke when they were minors, which are in incapable condition to make rational decisions. In this context, moral question emerge: Is the government obligated to prevent teenagers from taking-up cigarettes, and what should the government do to stop the smoking epidemic among the adolescents in Indonesia? To answer these questions, this paper contain two main study: First, the author has conduct a survey to present an overview about the ensnarement of new smokers and the dilemma of the tobacco retailers in selling cigarettes to minors in Indonesia. Second, the author presents an overview of the negative impacts of tobacco on children and an obligation analysis of the government to prevent adolescents from taking-up cigarettes. It will then propose some approach to stop smoking epidemic among the adolescents in Indonesia.
\end{abstract}

Keywords: addiction, adolescents, ensnarement, government, paternalism, smoking, tobacco control

\section{Introduction}

Tobacco is the most addictive substance that causes many deadly diseases in the world (DHHS, 2014), especially in Indonesia. A grim report from the WHO revealed that tobacco is the leading cause of preventable and premature death. Tobacco has killed an estimated six million people (active and passive smokers) every year worldwide, including in Indonesia (WHO, 2011). Empirical studies show that one in two smokers has died prematurely an average of 10-15 years earlier than non-smokers (DHHS, 2014; Jha et al., 2013).

In Indonesia, smoking epidemic has occurred among the adolescents, as the nearly six in ten of the youth of ages 13 to 15 years and nearly seven out of ten adult male are active smokers. The recent WHO report shows that smoking in the Indonesian teenagers has skyrocketed from $12.6 \%$ in 2006 to $23.5 \%$ in 2010 (WHO, 2013a). In fact, Indonesia had one of the highest smoking rates in the world at 36.1\% (64 million people) in 2011.

Indonesia has also been known as "the country of smoking baby", as some of the parent smokers in Indonesia have deliberately introduced the way of puffing cigarettes to their toddlers. For example, in 2010, a video on Youtube shows a two-year-old Indonesian child who smokes 40 cigarettes a day. This video has been watched by more than 27 million people around the world. This video has provoked outrage in the international community towards the Indonesian government and community.

In this context, ethical question emerge: Is the government obligated to prevent teenagers from taking-up cigarettes, and what should the government do to stop the smoking epidemic among the adolescents in Indonesia? To answer these questions, this paper contain two main study: First, the author has conduct a survey to present an overview about the ensnarement of new smokers and the dilemma of the tobacco retailers in selling cigarettes to minors in Indonesia. This study applies qualitative methodology as it is a useful tool to explore and analyze experiences and human opinions (Hennink, 2011). In order to get specific opinions and to allow the author in-depth interview with the participants of this study, direct interview with thematic guided questions (Table 1) was applied (Nkwi, 2001). Two groups of participant were recruited, namely one group of men smokers and other group is of cigarette retailers. The long of respondent experience as smokers is essential for this research; thus, the main recruitment criteria for the smokers participant is an active smokers for more than 4 years, and the main recruitment criteria for cigarette retailers is an active retailer for more than 5 years. Between March and July 2011, the author has selected and interviewed 100 smokers (25 employees and 75 students of the Samarinda State 
Polytechnic) and 10 cigarette retailers in Samarinda, East Kalimantan, Indonesia. The transcripts of the direct interview with the participants were analyzed by using thematic analysis (Braun, 2006). The author organized the transcripts' smoker respondents into three themes: try just for fun and then ensnare into perpetual addiction, underestimate the distal-health hazards of smoking, and living in dissonance. Two main themes were concluded from analyses of the retailer's transcripts, namely, maximizing profit is the main motivation and awkward in selling cigarettes to minors. From this survey unequivocally shows that most the new smokers has been ensnared by the tobacco industry, as they started to smoke when they were minors, which are in incapable condition to make rational decisions.

Second, author provide the negative impacts of tobacco on children and an ethical analysis of government obligation to prevent adolescents from taking-up cigarettes. It will then propose some approach to thwart smoking epidemic among the adolescents such as smoking ban, access restriction to tobacco products, prohibition of tobacco advertisements, anti-smoking campaigns, excise taxation, and reduced-nicotine content cigarettes.

\section{The Ensnarement of New Smokers and Dilemma of Cigarette Retailers in Indonesia}

\subsection{Smokers}

\subsubsection{Try just for Fun and then Ensnare into Perpetual Addiction}

As the immature persons, the adolescents have not yet capable to make good rational decisions. Their decision-making preferences toward smoking are more emphasized on the immediate emotional pleasure of the smoking rather than on its long-term health consequences. Incredulity of the adolescents toward health risks of tobacco and emotional pleasure in smoking has significantly influenced the smoking behavior of the adolescents. Nearly $90 \%$ of the respondents admitted that they started become smokers under 17 years old due to the cigarette advertising and peer pressure. All the $90 \%$ respondents revealed that they are strongly enticed by the emotional rewards to take up cigarettes, when they started smoking several years ago. They explained that they tried it just for fun adventure, as they imagined the features of cigarette advertisements.

The combination of the nicotine as a highly addictive substance and the brain of adolescents that are prone to an addiction have trapped adolescent smokers into severe nicotine addiction. All the respondents (which start smoking under 17 years old) have considered themselves as severe-addicted smokers. They have also become aware, that the longer they smoked the stronger their craving for cigarettes would become. Finally, they were committed to being smokers and then found themselves in a situation that is nearly impossible to quit smoking. They have experienced the severe withdrawal symptoms of nicotine addiction such as strong cravings, anxiety, irritability, restlessness, difficulty concentrating, and depressed mood.

Inability to control the symptoms of nicotine addiction is the main factor in the failure of smoking cessation among the respondents. About $91 \%$ of them have tried several times to quit but always failed or "tomorrow never come." They crave a cigarette every time after meals, hanging out with their friends, and drink coffee. During their cessation smoking programs, the withdrawal symptoms of nicotine addiction have resulted in traumatic experiences to the respondents, as a result, their cessation programs always failed. Due to the traumatic experiences, some of them even said: "I would prefer to break-up than quit of smoking."

Socio-economic activities of tobacco companies have also had a significant influence on smokers' motivation to quit smoking, including sponsorship and corporate social responsibility of the tobacco companies. Some of the respondents said: "I would not watch football games any more if I quit smoking because this sport is mainly sponsored by tobacco companies". Surprisingly, as the smokers, they believed that they have provided a positive contribution toward society and the government. They argued that the unemployment rate would rise if they quit smoking.

In addition, social gatherings (e.g., hang out with friends and traditional weddings) are a strong barrier of smoking cessation among the respondents, as the smoking and handing out of cigarettes at the social gatherings has become a social norm in Indonesia. All the respondents have conceded that they were unable to refuse an offer of cigarettes or smoking at the social gatherings because it would cost them socially and psychologically. In fact, nearly all the respondents have perceived that smoking is a vehicle for entering a desired friendship group. They try to look and act like their peers to avoid disapproval and negative judgments.

\subsubsection{Underestimate the Distal-Health Hazards of Smoking}

Tobacco companies' public relations and their socio-economic activities have also obscured the smokers' perception about the negative impacts of tobacco. Through these activities, the tobacco companies promote themselves as socially responsible enterprises and perpetually deny the health risk of tobacco. As a result, smokers constantly obtain a lot of second opinion information to doubt the health risks of smoking. The health-warning 
texts on the cigarette packs did not have significant influence on respondents' perception about the health hazards of cigarettes. Some of the respondents said: "Smoking could cause cancer but would not definitely lead to cancer." They considered that the warning texts are only to scare people from taking up cigarettes, and they even said this is a redundant. The respondents believed that they would not suffer the serious tobacco-related diseases because they are healthy. On the other hand, they firmly believed that the smokers who smoke cigarettes more than two packs a day would suffer the serious diseases.

The delay onset of the tobacco-related diseases has misled smokers to believe that they would stay healthy despite they have suffered light health problems, such as coughing and shortness of breath. Although around $97 \%$ of the respondents acknowledged that smoking is a bad for their health, they have firmly believed that smoking moderately would not lead to a serious health risk. All the respondents were not too worried about the health risk of smoking. Instead, they simply said: "It's okay just one pack every day."

Moreover, all the respondents are still in doubt about the scientific evidence of the tobacco-related diseases. The incredulity toward the scientific evidence has given an unrealistic hope among the respondents to stay healthy, while they smoke moderately. They perceived that it is a normal condition for the smokers to have the light health problems, such as coughing, flu, shortness of breath, and inability to run fast.

\subsubsection{Living in Dissonance}

Discrepancy between smoking behavior and desire to quit smoking among the respondents has demonstrated their remorse as smokers. The discrepancy has induced the smokers to experience a cognitive dissonance. After become smokers for several years, nearly all the respondents recognized that they have been victims from cigarette marketing and peer pressure. When they started smoking the cigarettes (before they are 17 years old), they never even thought that smoking is a self-destructive activity, but they just imagined that smoking is a fund activity, and they felt more "real boys" than the others. At this period, as adolescents, they are passionate adventurers to seek emotional experiences and self-identities. All the respondents agreed that at the time smoking for them is an activity that is laden with emotional experiences, and it is a symbol of courage.

As time went on, however, the respondents have also become more aware about the health risks of cigarettes and the health care costs of tobacco-related diseases. They have experienced negative-based emotions when they realized that their current situations would be better if they acted differently in the past. Nearly all of the respondents have answered "No" to the question: "If you had to do it over again, you would not have started smoking?" Unfortunately, around 91\% of the respondents have tried several times to quit smoking notwithstanding, they were always failed.

In addition, as the believers, only on the good and the right things that they would dare to say thank you God. As a result, none of respondents have answered "Yes" to the question: "Could you pray, thank you God that I smoke"? They simply replied: "I think nobody dares to pray like that". In contrast, in order to reduce their cognitive dissonances and to vindicate their failure to quit smoking, nearly all the respondents have rationalized their smoking behavior. They have perceived themselves as severe addicts, held unrealistic beliefs that they would stay healthy, underestimated the harmful effects of smoking, and misdoubted the evidence that smoking causes many deadly diseases.

\subsection{Cigarette Retailers}

\subsubsection{Maximizing Profit is the Main Motivation}

All the respondents (cigarette retailers) have had a good knowledge about the health hazards of cigarettes, such as lung cancer, heart attacks, impotency, and fetal disorders. On the other hand, they did not regret to sell the cigarettes, including to minors. They argued that tobacco products are legal for sale. The free choice principle is always used by cigarette retailers to justify their arguments that the health hazards of cigarettes are not part of their responsibilities as retailers. The respondents demanded that smokers themselves should be aware about the health hazards of smoking. High return from the sale of cigarettes is the main reason of the retailers to sell the tobacco products. They said: "I sell cigarettes because they yield higher profit than the others." All the retailers revealed that the cigarettes are result in the most sales compared with the other consumer goods in their stores. As in the recent years, many people have become smokers, especially adolescents.

To justify their sale of cigarettes as harmful and addictive products, the retailers honestly admitted that they face a dilemma in the sale of cigarettes. As the profit from their store is the main income for their family, which is much of the profit come from the cigarettes. Consequently, when they stopped to sell the cigarettes, including to minors, they would lose significant profit from their store to another kiosk or store that kept on selling cigarettes. Surprisingly, most of the retailers requested the government to regulate the cigarette marketing or even to close 
down the cigarette factories, and thus they would sell other consumer goods. They considered that these problems are most likely to continue due to the very few of regulations to control the cigarette marketing in Indonesia.

\subsubsection{An Awkwardness in Selling of Cigarettes to Minors}

Everyone agrees that children and adolescents are immature persons that should be prevented from take up cigarettes, including the cigarette retailers themselves. All the respondents (cigarette retailers) are aware about the dilemma of selling cigarettes to the children and adolescents. They honestly recognized that selling cigarettes to the minors is unethical behavior. The retailers also revealed that they were deeply annoyed when they saw children smoking cigarettes. On the other hand, the retailers have also known that the minors are the main source of the new smokers and their new customers. As a result, the retailers have no other choice but to sell the cigarettes to the minors. All the retailers have simply admitted that they have sold the cigarettes to children and adolescents. Even though the retailers have experienced the ethical dilemma, they always use many cogent reasons to rationalize the sale of cigarettes to minors.

To vindicate their sale of cigarettes to the minors, the retailers demanded that this problem is not their responsibility but the parents of the minors. The retailers also argued that the boys were perhaps sent by their fathers or brothers to buy cigarettes. Indeed, in Indonesia, children are commonly sent by their fathers or brothers to buy coffee or cigarettes in the nearby kiosk. In contrast, they asserted that they would never allow their own sons to smoke (some of them also have sons).

\section{The Negative Impacts of Tobacco on Children in Indonesia}

According to the Indonesian statistics agency (BPS), monthly expenditure per capita for cigarettes among the families in Indonesia was always second after rice. The poor urban smokers spent around $22 \%$ of their weekly income on cigarettes (Semba et al., 2007). In 2012, data from the Indonesian Ministry of Health shows that the lowest-income families consume an average of 12 cigarettes daily. In other words, they have spent up to $40 \%$ of their income on cigarettes. As a result, smoking has had a huge impact on the children in the poor family smokers in Indonesia, especially malnutrition and education problem. Some studies (Best et al., 2008; Semba et al., 2007) show that the low expense on health and nutrition among the poor family smokers has a significant impact on increasing malnutrition in their toddlers. Premature death of fathers as a family breadwinner also has increased the rate of school drop-out (Barber et al., 2008). Moreover, mortality rate of the children under the age of five years and infant was also higher in families in which the father was a smoker than in those with a nonsmoking father (Semba et al., 2008).

Several studies (KJ. Lee, 2014; Loukola et al., 2014; Boden et al., 2010) show that development of severe depression among adolescent smokers strongly associated with smoking, and the same depression also experienced by adolescent passive smokers. Moreover, depression in adolescents also positively linked to their smoking behavior; thus, their depressions are even worse than before (Parrott \& Murphy, 2012; Windle, M. \& Windle, R. C., 2001; Goodman \& Capitman, 2000). Empirical evidence shows that the adolescents who suffer from depression face a substantially increased probability of engaging in property crime (Anderson et al., 2012). In fact, research shows that smokers with depression experienced more severe negative moods on quitting and this is a powerful trigger for relapse (Gierisch et al., 2010).

Smoking has induced bad behaviors among adolescent smokers in Indonesia, especially stealing to buy cigarettes. For example, in order to buy cigarettes, several Indonesian teenage smokers have been arrested by police for stealing (Polda DIY, 2013; Tempo, 2012). They have often stolen money at neighbor houses or in the mosque's charity boxes. Some studies have revealed that stealing behavior positively associated with smoking among adolescents, especially stealing of cigarettes (Lenk et al., 2014; Grant et al., 2011).

Some research (Boutwell \& Beaver, 2010; Martin \& Dombrowski, 2008) has revealed that prenatal exposure to tobacco smoke is related to various negative outcomes, including reduced cognitive abilities, later-life health problems, and childhood behavioral problems. In 2010, in Indonesia, approximately $70 \%$ pregnant women exposed to secondhand smoke as their husbands smoke at home. In fact, a recent study shows that cigarette smoke has resulted in lasting damage to children's arteries and prematurely ageing their blood vessels by more than three years (Gall et al., 2014). Smoking during adolescence is a risk factor for abdominal obesity among young adults (Saarni et al., 2009), and both smoking and obesity abdominal are major risk factors for metabolic dysfunction and cardiovascular diseases (Jiang et al., 2013; Manson et al., 2000). According to the WHO, cardiovascular diseases are the leading cause of global mortality, accounting for 30\% of all global deaths. In 2008, more than 17 million people died from the cardiovascular diseases. 
Indonesian adolescent smokers face a serious threat from tobacco-related diseases, which is likely half of them will die prematurely, as only around $4 \%$ of the smokers in Indonesia have successfully stopped smoking. All the negative effects of tobacco suffered by teenage smokers and passive smokers among the children are not the result of their own genuine choices, but rather inflicted by others.

\section{An Obligation Analysis of the Government to Prevent Children from Taking-Up Cigarettes}

\subsection{Human Rights to Life and Health: Protecting Adolescents from Smoking}

Nearly all the smokers start before adulthood, at the time when the capacity for rationalized, long-term decision-making is not yet fully developed. In Indonesia, most adolescent smokers have suffered from the negative impacts of smoking. Consequently, the negative impacts of tobacco have hampered the future development of the Indonesian adolescent smokers. Human rights were established to protect the fundamental values such as the ability to live, have a family, and be free from cruel treatment. The Universal Declaration of Human Rights (UDHR) has firmly declared that the fundamental rights such as the right to life and health, should be ensured by the government. The article 6 of the Convention on the Rights of the Child (CRC) was established to ensure the maximum extent possible the survival and development of the child. However, the hesitance of the Indonesian government to enact stricter tobacco control regulations is clearly denoted by the latest government regulation No.109 in 2012 on tobacco products that has not yet reflected the main purposes of the Framework Convention for Tobacco Control (FCTC) to prevent adolescents from starting to smoke. Bentham (1987) has firmly declared that the concept of human rights is no more than imaginary rights until the government enacts laws to ensure the rights. Thus, individuals that support tobacco control, may make the human rights arguments to urge their government to enact tobacco control laws.

\subsection{Ethical Issues of Smoking among Teenagers}

Rational addiction theory (Becker \& Murphy, 1988) states that smoking is a rational decision in the economic realm. Smokers as rational consumers face a trade-off between presents gains and future costs, and they decide to smoke if they are willing to pay the price: the cigarette price at present and future health costs. This theory implies that people who are incompetent condition to make rational decisions would be easier to take up cigarettes than those who are competent. More precisely, new smokers mainly come from the incompetent people. According to Carter (2004), freedom of choice describes an individual's opportunity and autonomy to perform an action selected from at least two available options, unconstrained or forced by external parties. In order to perform a free choice, an individual has got cognitive ability to make rational decisions, as in economic realm, when individuals perform free choices they should realize their best interests.

One of the most important personal interests is to become an ethical individual agent in society, for the individuals which perform unethical free choices will not only suffer negative consequences from their choices but also they will receive stigmatization from the society. Ethical Egoism, an ethical theory from ancient Greece, emphasizes that an individual should be an "enlightened" ethical egoist; that is, one should have a cognitive ability to predict of what will inure to one's benefit in the long-run, and accordingly be ready to sacrifice some short-term pains or expenses to attain a greater long-term good. In one of the formulations Kantian ethics states that human beings (whether the agent or another) should be treated as an end rather than merely as a means; thus, any actions must be based on rationalities and sincere motives. This formulation implies that any free choices will produce impacts on the agent and others (society); thus, individual agents have to treat themselves as end rather than merely as means by others. In this context, an ethical free choice entails cognitive abilities of individual agents to make rational decisions and to assess their motives.

Smoking among teenagers cannot be classified as an ethical choice due to the two reasons. First, the teenagers as minors are considered as incompetent people to make rational decisions. Some scientific evidence shows that teenagers are in incapable condition to make rational decisions due to their brains are not fully developed as mature persons (Konrad et al, 2013; Giedd et al, 1999).

Second, smoking among teenagers is merely respondent conditioning by tobacco advertisements. As demonstrated by Pavlov, respondent conditioning occurs when a stimulus (a feature favored by exposer) that brings forth a response is paired with another stimulus (e.g. cigarettes or smoking) that originally wouldn't cause that response. Over time, the paired stimulus will bring forth the same response as the first stimulus. The paired stimulus has eventually associated with the first stimulus (Bower, 1979; Lazev et al., 1999). Tobacco advertisements usually contain features that most favored by adolescents. Thus, the adolescents, which are frequently exposed to tobacco advertisements, most likely will become smokers (Hanewinkel et al, 2010; Shadel et al., 2008). Some research (Goodin, 1989; Hoek et al., 2013) have revealed that the adolescents, which have made decisions to taking up cigarettes, were actually under conditioned by external factors (e.g. by peers or cigarette advertisements). Some 
neuroscience research (Chein et al., 2011; \& Steinberg et al., 2009) has validated that the heightened risk-taking during adolescence is mostly driven by biological factors to produce dopamine that plays a critical role in the brain's reward circuitry. In making a decision, the adolescents prefer to instantly emotional gratification than to logical reasoning; thus, they tend to be a sensational seeker, short-sighted, and susceptible toward peer pressure.

Smoking among adolescents are no longer their genuine free choices, rather the adolescent smokers have been conditioned by others to take-up cigarettes. Adolescent smokers are obviously considered as victims, in other words, adolescent smokers have been exploited by the tobacco industry. In this regard, the government intervention required to protect the children from the exploitation.

\subsection{Paternalism Ethics}

The state as political institution and sovereign entity that represented by the government possesses the inherent authority (police power) to govern and protect public interest, including to enact and to enforce public health laws (Philpott, 2014). According to the Jeremy Bentham (Bennett, 2010), all laws divided into three categories: (a) laws designed to protect people from harm caused by others; (b) laws designed to protect people from harm caused by themselves (legal paternalism); and (c) laws obligate people to help and assist others (Good Samaritan laws).

Legal paternalism obligates the government (state) to protect the incompetent people, especially children, from the undesirable consequences of their own actions. Paternalism comes from the Latin word "pater", meaning to act like a father, or to treat another person like a child. Libertarians, of course, believe that the government has no right to regulate what people should do as long as their actions harm no one else, and thus let them to bear the consequences of their own actions. However, they tend to agree at some degree that paternalistic actions are required to protect the immature persons (children) from harming themselves (Hospers, 1980). Errors in choices by adolescents specifically arise from unstable emotion and the limits of cognitive capacity.

To some extent, preventing minors with coercion from future bad consequences can be regarded as an application of the Good Samaritan law; thus, perhaps all parents have at some time used the coercion to prevent some harm to their children or bring about some good (Oriola, 2009). As a result, most likely all people are grateful for their parent's coercion in the past. The deprivation of smoking in children by laws is justified by reasons referring exclusively to their best welfare and interest rather as punishment (Dworkin, 2014). Paternalism was the appropriate social response for those who were to be treated ultimately as wards of the state, especially adolescents. In fact, a number of strict regulations in the developed countries reflect that even people of sound mind might not act in their best self-interest in certain predictable situations. Moreover, in secular world, incorporation of morality into formal laws doesn't only protect the incompetent people from harming themselves and exploitation, but it also encourages ethical actions in society. In this context, the government both ethically and legally is obligated to enact laws in order to prevent children from smoking.

\section{The approach to Stop Smoking Epidemic among Adolescents}

\subsection{Prohibition of Smoking and Cigarette Purchase in Adolescents}

The Framework Convention for Tobacco Control (FCTC) is currently the most pertinent tool for implementation of the right to health of the child into tobacco control regulations, as the main purpose of the FCTC is to prevent adolescents from starting to smoke and to protect non-smokers from second-hand smoke. Unfortunately, Indonesia is the only World Health Organization (WHO) member state in Southeast Asia that has not ratified the FCTC. In Indonesia, approximately more than $80 \%$ of smokers start by age 18 and virtually all by 26 (WHO, 2012); thus, preventing youth initiation is also considered as the most important effort to ending the tobacco epidemic in Indonesia.

Prohibition of both the smoking and buying tobacco products among adolescents will severely restrict their access to cigarettes, as this ban is also meant to prohibition of selling or providing cigarettes to children. Thus, it will significantly reduce smoking among the adolescents. In fact, provision of fines on the selling or providing of cigarettes to children is obviously required to discourage anyone to exploit the children, as the sale of cigarettes to children not only generate profit but it is also as the main tool to recruit new smokers from this age group.

In addition, given the tobacco has a substantially higher risk of causing addiction than heroin, cocaine, alcohol, or cannabis (SCENIHR, 2010), and some research shows that youths, in particular, are the most prone to severe dependent on nicotine addiction (DHHS, 2012; DiFranza et al., 2007). Consequently, it is nearly impossible for the teenager smokers to quit smoking. Some studies have revealed that nicotine addiction is the central role of chronic smoking behavior in adolescents (Selyaa et al., 2013; Dierker \& Mermelstein, 2010). A study (Aditama et al., 2008) shows that in Indonesian about $90 \%$ of the youth smokers have tried few times to quit smoking but have always failed. In fact, data from Basic Health Research (Riskesdas) shows that from 2007 to 2013, only about 
$4.1 \%$ of the Indonesian smokers have successfully stopped smoking, including the adolescents. In this regards, prohibition of smoking and cigarette purchase in adolescents would significantly reduce smoking epidemic in Indonesia.

Empirical evidence shows that implementation of smoking ban on adolescents in developed countries has significantly reduced smoking among the adolescents. In USA, smoking among students has significantly decreased from $27.5 \%$ in 1997 to $15.7 \%$ in 2013 (CDC, 2014a), and smoking among adults have linearly declined from $20.9 \%$ in 2005 to $17.8 \%$ in 2013 (CDC, 2014b). In Canada, smoking among adults sharply declined from $25 \%$ in 1999 to $17 \%$ in 2011. Similarly, in Canada, smoking among adolescents has steeply decreased from $45 \%$ in 1994 to 13\% in 2013 (Health Canada, 2014). In Australia, as one of the countries' most stringent in tobacco control, smoking among adolescents (aged 13 to 17 years) over the last decade has fallen from $23 \%$ in 1999 to $8.5 \%$ in 2011 (Scollo \& Winstanley, 2012).

Prohibition of buying cigarettes has significantly discouraged American adolescents to buy cigarettes by themselves, as the country has experienced linearly decline in adolescents' access to cigarette sources-from 19\% in 2001 to $18.1 \%$ in 20013 (CDC, 2014a). In Australia, the adolescents of 12-15 year olds reported buying their last cigarette themselves down from $17 \%$ in 2005 to $12 \%$ in 2008 (AIHW, 2013).

\subsection{Enforcing Ban on Cigarette Marketing toward Teenagers}

Advertisement plays an essential role to persuade consumers (the target segment) to consume or use a product, especially tobacco advertisements toward adolescents (NCI, 2008; Nairn \& Berthon, 2003). The desires of smoking in adolescents mostly triggered by tobacco advertisements which featured by pleasure of smoking and cool images. The weaknesses of teenagers such as the receptivity to advertisements, incompetent to make rational decisions, and the seekers of sensational experiences, have properly managed by tobacco companies to advertise their tobacco products toward the teenagers (Gilpin et al., 2007; Feighery et al., 1998). Some research has confirmed that adolescents' smoking initiation is strongly associated to their receptivity to tobacco advertisements (Emory et al., 2013; Lovato et al., 2011). In fact, empirical research shows that tobacco display at the point of sale has a significant influence on smoking behavior among adolescents (Spanopoulos et al, 2013; AE. Kim et al., 2012).

To target adolescents, the tobacco companies have introduced new brands "mild", "light", and "low-tar" (S. Lee et al., 2012; Henriksen, 2012). Furthermore, as menthol is a favorite flavor among adolescents, the tobacco industry intentionally has used it as an additive in cigarettes to recruit the adolescents to smoking, and it will discourage them to quit smoking (Glantz, 2013; DKFZ, 2012). In order to maintain the adolescents as perpetual smokers, tobacco companies have controlled the nicotine content in their cigarettes to create and sustain addiction (TCLC, 2006). Scientific evidence has confirmed that most adolescent smokers are addicted and find it hard to quit smoking (DHHS, 2012; Mendelsohn, 2011).

To appear attractive toward adolescents, tobacco kiosks have been decorated with pictures of cigarette advertisements that purposely provided by tobacco companies. Some studies have confirmed that to increase their sale, Indonesian tobacco companies aggressively used small retailer outlets to advertise and to market tobacco products, especially to adolescents (Mardian, 2011; Nichter et al., 2009).

It has long been known that tobacco companies have directly promoted tobacco products through their sponsorship activities toward youths (Brown \& Williamson, 1979), as the tobacco companies have intentionally displayed cigarette brands in the sponsorship activities, which attended or viewed by the youths. In other words, tobacco companies deliberately funded the events that mostly favored by teenagers as a marketing scheme such as sports and music concerts. In fact, most adolescents perceive that tobacco companies' sponsorship events are positive contributions to toward society. Therefore; through the sponsorship events, tobacco companies have instilled their good image in youth, and this good image encourages youths to take up cigarettes (Vaidya et al., 1999; SC, 1996). Moreover, during the events that were attended by children, there were cigarette booths with sales promotion girls that offered the cigarettes to visitors, including the children.

Tobacco companies have not only used their philanthropic activities such as scholarships to promote good image to society but also to introduce their company profiles and tobacco products toward adolescents (S. Lee et al., 2012; Tandilittin \& Luetge, 2015). For example, since its establishment in 2001, Putera Sampoerna Foundation (PSF) has disbursed more than 34,600 scholarships to Indonesian students, and adopted 23 public and 5 Islamic elementary schools.

In this context, to prevent the minors from harming themselves and exploitation by the tobacco industry, the government as a paternalistic institution should prohibit target marketing of tobacco products toward children through legislations. In addition, encouraging or persuading children to taking-up cigarettes is considered as 
immoral behavior according to virtue and deontological ethics. Virtue ethics has firmly declared that target marketing on youth consumer segments viewed as "vulnerable targets" with harmful products, especially tobacco products, is an unethical marketing practice (Smith \& Cooper-Martin, 1997), as the youths considered as immature persons.

The insistence of deontology on equal respect for all doesn't allow maximizing profit at the expense of some people, including the sale of cigarettes to teenagers; therefore, a certain (harmful) action should not be performed, even to maximize utility (van staveren, 2007). Unfortunately, it is nearly impossible for tobacco companies to prevent themselves from marketing of their tobacco products toward teenagers, as they are the main source of new smokers. Instead, the tobacco companies may have no other choice but to sell cigarettes to minors. For example, the limited efforts of the Indonesian government to control cigarette advertising have resulted in multinational tobacco companies to adapt their policies to suit the situation, such as British American Tobacco (BAT) has prohibited advertising that associates smoking with successful people or sexual prowess, but BAT has exempted itself from the policy in Indonesia (Bland, 2013).

According to the WHO, implementation of the article 13 of the Framework Convention on Tobacco Control (FCTC) that entails a comprehensive ban on tobacco advertising, promotion and sponsorship, including all forms of commercial communication and all forms of contribution to any event, activity or individual, will significantly reduce the exposure of teenagers to marketing of tobacco products (WHO, 2008).

\subsection{Anti-Smoking Campaigns}

Smoking in adolescents is instilled through a variety of ways, especially through social interactions and cigarette advertising. In Indonesia, cigarette smoking has become a social norm, as the cigarettes are one of the main items to greet guests at almost all of important social gathering such as traditional weddings and funerals, which are an opportunity for adolescents to take up cigarettes. Smoking also has been perceived as a symbol of masculinity by Indonesian male adolescents (Ng et al., 2007). In addition, adolescents have considered that smoking is a vehicle for entering a desired friendship group. They try to look and act like their peers to avoid disapproval and negative judgments. Thus, smoking has apparently become an imperative activity among Indonesian male teenagers.

Tobacco companies have been purposely inducing a good image about smoking among adolescents through tobacco advertising and promotions (NCI, 2008), as the adolescents are the main source of new smokers. In families with heavy television and movie viewing habits, they may be more likely to perceive smoking as normative (Strausburger et al., 2010). Moreover, through their sponsorships and philanthropic activities, the tobacco companies have managed to convince the adolescents, that through smoking, however, they have provided positive contributions to society. The Indonesian adolescents have become the main target of cigarette marketing by tobacco companies, as the cigarette marketing are always associated with adolescents, including cigarette advertising featured by young celebrities, cigarette packs designed attractive, and favorite events among the adolescents sponsored by the tobacco companies (S. Lee et al, 2012; Nichter et al, 2009). Empirical research has confirmed that approximately $90 \%$ of Indonesian adolescents have been exposed by the tobacco advertising and promotion (GYTS, 2009).

Smoking in adolescents is not because of they do not think that smoking will not harm their health, but smoking will gives them pleasure. Thus, most of adolescent smokers admitted that the smoke fear-based warnings were not considered to discourage them from smoking. Through their marketing strategies, public relations, and social activities, the tobacco companies in Indonesia have promoted the good image of smoking. Tobacco advertisements that always associated with positive image such as cool, fun, masculine, and attractive have precisely resulted in to encourage adolescents to take up cigarette. The Indonesian tobacco companies have also utilized their corporate social responsibility activities such as scholarships to student and education facilities to instill their good images among Indonesian students. In this context, anti-smoking campaigns is required to chance the smoking perceptions in Indonesian teenagers that have been built by the tobacco industry.

Empirical studies have confirmed that anti-smoking campaigns have a significant influence in changing the smoking perception among adolescents, and it also has significantly reduced smoking in California (Liu \& Tan, 2009). Appropriate approaches are required to change the adolescent perceptions about smoking that have been instilled in their minds through tobacco advertisements and social interactions. In their economic modeling, Olekalns and Bardsley (1999) shows that one-way communication of anti-smoking advertisements and education had mixed effect on smoking behavior in adolescents. They suggested that two-way communication and target-segmented approach is probably more efficient in controlling this tobacco epidemic. A recent research (A. Brown \& Moodie, 2012) suggests that effective communication had a significant influence on change of smoking perception in teenagers. 
As a paternalistic and communal society, a combination of school- and home-based anti-smoking discussion about the negative impacts of smoking would be effective in the control of adolescent smoking in Indonesia (Rao, 2014). Indonesian adolescents spend around 5 hours daily to watch television (Nielsen, 2009). Therefore, parents may impose limits on how much and what type of programs on television their children might watch and they may disapprove of their children owning cigarette promotional items. In fact, the tobacco control civil society organizations have important roles to disseminate scientific-based information about negative impacts of tobacco, especially to adolescents (Tandilittin \& Luetge, 2013).

Moreover, anti-smoking campaigns should also be addressed to tobacco retailers. As they are the forefront agents in the supply chain of cigarettes. The unwillingness of the tobacco retailers to sell the cigarettes to teenagers is one of the most crucial factors to reduce smoking epidemic in Indonesia. A previous study revealed that nearly $90 \%$ of the Indonesian adolescent smokers have bought cigarette in bars by themselves at cigarette retailers (Martini \& Sulistyowati, 2005). Although the USA has been strictly implementing tobacco control, more than half of teenagers perceived that cigarettes would be very easy to buy at the convenient stores (Johnston et al., 2013). Moreover, tobacco companies have aggressively used the retailer outlets to advertise and to market tobacco products to adolescents (Moreland-Russell et al., 2013).

\subsection{Excise Taxation}

It is well established that increase of cigarette prices have been found to decrease adolescent smoking initiation and to prevent young smokers from moving beyond experimentation into regular daily smoking. Some studies (WHO, 2015; Chaloupka et al, 2010; Wakefield et al., 2002) show that increased tobacco prices at retail outlets has a significant influence to deter smoking initiation among adolescents. The increase of cigarette prices would significantly reduce smoking epidemic in Indonesia, which are dominated by male smokers, as the smoking initiation among teenage males has been found to be much more responsive to changes in cigarette prices than has been initiation among teenage females (Zhang et al., 2006). In fact, increased price of cigarettes can thwart young smokers from increasing their level of addiction to nicotine by preventing the move from the category of light smokers to the category of heavy smokers (HC. Kim et al, 2012; Gordon et al., 2015).

According to the World Bank, tax as a proportion of the total cigarette price should be on an average from 65 per cent to 80 per cent of retail price. In its recent report, WHO has asserted that the increase of tobacco taxes to more than $75 \%$ of the retail price is among the most effective and cost-effective tobacco control interventions (WHO, 2015). Currently, in Indonesia, tobacco taxes are only on an average $45 \%$, which is far below the rate recommended by the World Bank. Consequently, the cigarette price in Indonesia is cheap, and it is then affordable toward adolescents. Furthermore, the sale of cigarettes in bars by Indonesian retailers has led the cigarette prices to extremely affordable for the adolescents, and thus this condition precisely encourages teenagers to take up the cigarettes.

In addition, to make the cigarettes more affordable, promotional allowances at the retail outlets are the most sophisticated marketing of the tobacco industry to reach adolescents. A recent study in Indonesia has confirmed that to increase its sale, tobacco company focuses its promotional allowances on cigarette retailers (Mardian, 2011). According to some studies (IARC, 2011; \& Gilmore et al, 2010), the tobacco industry has allocated most of their marketing expenditures on the pricing strategy, especially incentive payments to retailers. Tobacco companies have a vested interest in the profit of cigarette retailers, as the high profit margin from cigarette sale would encourage the retailers to devotedly sell the cigarettes.

\subsection{Reducing Nicotine Content in Cigarettes}

Nicotine is a highly addictive substance in tobacco, and thus it is primarily responsible for the dependence of smokers on cigarette smoking. Nicotine addiction has undermined the freedom of choice and rational addiction decision with respect of smoker choices to stopping or keeping the use of the cigarettes, especially adolescents. It is clearly established that nearly all the young smokers have tried few times to quit smoking, but the nicotine addiction has trapped them into perpetual dependence on smoking cigarettes.

Tobacco companies have purposely designed and manufactured their cigarettes to create dependence potential and attractiveness in smokers; thus, demand of the tobacco products would increase over time. The intent of tobacco companies to increase the use of cigarettes that utilized the trap of nicotine dependence in smokers, have undermined the prevention, cessation and tobacco control measures, especially among adolescents. Therefore, to reduce smoking epidemic among teenagers and to improve public health, a regulatory framework to regulate the dependence potential and attractiveness of tobacco products is imperative required.

Article 9 of the FCTC specifically requires to develop guidelines for testing, measuring, and regulating the contents and emissions of tobacco products, and to formulate a regulatory framework to reduce the dependence 
potential of tobacco products. In fact, nicotine reduction in cigarettes is to create non-addictive cigarettes; thus, the novice smokers such as teenagers which only experiment with smoking, will not move from occasional to addict smokers. In this regard, the later free choices are still available for teenage smokers to truly reconsider the benefits versus risks of smoking or not smoking and to then act on their decision to quit if that is their choices rather they have been trapped by nicotine addiction. The WHO has confirmed that one third of adolescents experiment with cigarettes as a result of exposure to the tobacco advertisements, sponsorships, and promotions (WHO, 2013b), and nearly all of them have been trapped by nicotine addiction.

Empirical studies reveal that the nicotine-reduced cigarettes did not resulted in smokers to take up more cigarettes (Benowitz et al., 2007; Benowitz et al., 2012; Benowitz \& Henningfield, 2013). Thus the reduction of nicotine in cigarettes would not increase exposure of tobacco toxicants toward smokers. A study shows that the smokers who used very low nicotine content cigarettes $(0.05 \mathrm{mg}$ per cigarette) did not reported withdrawal symptoms of nicotine addiction, and this type of cigarette has also increased the success rate of smoking cessation in the smokers who interested in quitting (Hatsukami, 2010).

\section{Conclusion}

People will voluntarily abstain from immoral actions only if the obedience to moral norms generates greater advantages in the long-term than defection in the single case at the present. Unfortunately, cigarette manufacturers and cigarette retailers will suffer a great loss in both the short-term and in the long-term if the new smokers are not come from the teenagers. As the legal paternalistic institution, the Indonesian government should be incorporated ethics into laws to prevent children from taking-up cigarettes and to protect them from exploitation by tobacco industry, for the nearly $90 \%$ of new smokers come from the teenagers. The ratification of the FCTC by the Indonesian government will be an important step to stop epidemic of smoking among teenagers. To hamper smoking initiation among Indonesian adolescents, the Indonesian government should increase excise taxes on tobacco products in accordance with the World Bank recommendation and prohibit sale of cigarette in bars. Finally, to assure later free choice and to thwart dependence risk of cigarette among adolescents, the government should compel tobacco companies to also produce the nicotine-reduced cigarettes, because most young-addicted smokers are nearly impossible to quit.

\section{Acknowledgements}

We acknowledge the Samarinda State Polytechnic, East Kalimantan and Directorate General of Higher Education, Ministry of National Education, Indonesia, for their scholarship.

\section{References}

Aditama, T. Y., Pradono, J., Rahman, K., Warren, C. W., Jones, N. R., Asma, S., \& Lee, J. (2008). Linking Global Youth Tobacco Survey (GYTS) data to the WHO Framework Convention on Tobacco Control: the case for Indonesia. Prev Med, 47(suppl 1): S11-14. http://dx.doi.org/10.1016/j.ypmed.2008.05.003

Australian Institute of Health and Welfare (AIHW). (2013). Risk factors. Retrieved August 1, 2014 from http://www.aihw.gov.au/ child-health/risk-factors/

Anderson, D. M., Cesur, R., \& Tekin, E. (2012). Youth depression and future criminal behavior. NBER Working Paper No.18656. http://dx.doi.org/10.3386/w18656

Barber, S., Ahsan, A., Adioetomo, S. M., \& Setyonaluri, D. (2008). Tobacco economics in Indonesia. Paris: International Union against Tuberculosis and Lung Disease.

Becker, G. S., \& Murphy, K. M. (1988). A theory of rational addiction. J Polit Econ, 96(4), 675-700. http://dx.doi.org/10.1086/261558

Benowitz, N. L., Hall, S. M., Stewart, S., Wilson, M., Dempsey, D., \& Jacob III, P. (2007). Nicotine and carcinogen exposure with smoking of progressively reduced nicotine content cigarette. Cancer Epidemiol Biomarkers Prev, 16, 2479-485. http://dx.doi.org/10.1158/1055-9965.EPI-07-0393

Benowitz, N. L., Dains, K. M., Hall. S. M., Wilson, M., Dempsey, D., \& Jacob III, P. (2012). Smoking behavior and exposure to tobacco toxicants during 6 months of smoking progressively reduced nicotine content cigarettes. Cancer Epidemiol Biomarkers Prev, 21, 761-769. http://dx.doi.org/10.1158/1055-9965.EPI-11-0644

Benowitz, N. L., \& Henningfield, J. E. (2013). Reducing the nicotine content to make cigarettes less addictive. Tob Control, 22(Suppl 1), i14-i17. http://dx.doi.org/10.1136/tobaccocontrol-2012-050860

Bennett, J. (2010). An Introduction to the Principles of Morals and Legislation. Retrieved August 12, 2015 from http://www.earlymoderntexts.com/assets/pdfs/bentham1780.pdf 
Bentham, J. (1987). Anarchical fallacies and supply without burden. In Waldron J, ed. Nonsense on stilt: Bentham, Burke, and Marx on the rights of mans (pp. 46-69). Methuen, London: Routledge.

Best, C. M., Sun, K., de Pee, S., Sari, M., Bloem, M. W., \& Semba, R. D. (2008). Paternal smoking and increased risk of child malnutrition among families in rural Indonesia. Tob Control, 17, 38-45. http://dx.doi.org/10. 1136/tc.2007.020875.

Bland, B. (2013, May 9). Tobacco groups race to recruit Indonesian smokers. Financial Times. Retrieved August 7, 2014 from http://www.ft.com/intl/cms/s/0/afb09252-b2fb-11e2-95b3-00144feabdc0.html?siteedition $=$ intl\#a xzz2dYAnuaz2

Boden, J. M., Ferguson, J. M., \& Horwood, R. J. (2010). Cigarette smoking and depression: tests of causal linkages using a longitudinal birth cohort. Br J Psychiatry, 196, 440-446. http://dx.doi.org/10.1192/bjp.bp.1 09.065912 .

Boutwell, B. B., \& Beaver, K. M. (2010). Maternal cigarette smoking during pregnancy and offspring externalizing behavioral problems: A propensity score matching analysis. Int. J. Environ. Res. Public Health, 7, 146-163. http://dx.doi.org/10.3390/ijerph7010146.

Bower, T. G. R. (1979). Human development. San Francisco, CA: W.H. Freeman \& Co.

Brown \& Williamson (internal industry document). (1979). Guidelines on communication restrictions and new opportunities in marketing. Jestburg. Bates no. 670828367/8381. Retrieved August 21, 2014 from http://legacy.library.ucsf.edu/tid/fqr03f00

Brown, A., \& Moodie, C. (2012). Adolescents' perceptions of tobacco control measures in the United Kingdom. Health Promot Pract, 13(1), 41-47. http://dx.doi.org/10.1177/1524839910369222

Carter, I. (2004). Choice, freedom, and freedom of choice. Social Choice and Welfare, 22(1), 61-81. http://dx.doi.org/10.1007/s00355-003-0277-z

U.S. Centers for Disease Control \& Prevention (CDC). (2014a). Youth risk behavior surveillance - United States, 2013, CDC surveillance summaries. Morbidity \& Mortality Weekly Report, 63, 4.

U.S. Centers for Disease Control \& Prevention (CDC). (2014b). Current cigarette smoking among adult—United State, 2005-2013. Morbidity and Mortality Weekly Report, 63(47), 1108-1112.

U.S. Centers for Disease Control \& Prevention (CDC). (2012). Youth Risk Behavior Surveillance - United States, 2011, CDC Surveillance Summaries. Morbidity \& Mortality Weekly Report, 61(SS04), 1-162.

Chaloupka, F. J., Straif, K., \& Leon, M. E. (2010). Effectiveness of tax and price policies in tobacco control. Tob Control. http://dx.doi.org/10.1136/tc.2010.039982

Chein, J., Albert, D., O’Brien, L., Uckert, K., \& Steinberg, L. (2011). Peers increase adolescent risk taking by enhancing activity in the brain's reward circuitry. Dev Sci, 14(2), F1-F10. http://dx.doi.org/10.1111/ j.1467-7687.2010.01035.x.

U.S. Department of Health and Human Services (DHHS). (2014). The health consequences of smoking - 50 years of progress: A report of the surgeon general. Atlanta, GA: U.S. Department of Health and Human Services, Centers for Disease Control and Prevention, National Center for Chronic Disease Prevention and Health Promotion, Office on Smoking and Health.

U.S. Department of Health and Human Services (DHHS). (2012). Preventing tobacco use among youth WHO and young adults: A report of the Surgeon General. Atlanta, GA: U.S. Department of Health and Human Services, Centers for Disease Control and Prevention, National Center for Chronic Disease Prevention and Health Promotion, Office on Smoking and Health.

Dierker, L., \& Mermelstein, R. (2010). Early emerging nicotine-dependence symptoms: a signal of propensity for chronic smoking behavior in adolescents. J. Pediatr, 156, 818-822; http://dx.doi.org/10.1016/j.jpeds.20 09.11 .044

DiFranza, J. R., Savageau, J.A., Fletcher, K., O’Loughlin, J., Pbert, L., ... Wellman, R. J. (2007). Symptoms of tobacco dependence after brief intermittent use. Arch Pediat Adol Medi, 161(7), 704-710.

German Cancer Research Center (DKFZ). (2012). Menthol capsules in cigarette filters increasing the attractiveness of a harmful product. Heidelberg: Germany. Retrieved August 19, 2013 from http://www.dkfz. de/de/tabakkontrolle/download/Publikationen/RoteReihe/Band_17_Menthol_Capsules_in_Cigarette_Filters _en.pdf 
Dworkin, G. (2014). Paternalism; Stanford encyclopedia of philosophy (N. Z. Edward Ed.). Retrieved August 23, 2014 from http://plato.stanford.edu/archives/sum2014/entries/paternalism

Emory, K. T., Messer, K., Vera, L., Ojeda, N., Elder, J. P., Usita, P., \& Pierce, J. P. (2013). Receptivity to cigarette and tobacco control messages and adolescent smoking initiation. Tob Control. http://dx.doi.org/10.1136/ tobaccocontrol-2013-051187.

Feighery, E., Borzekowski, D., Schooler, C., \& Flora, J. (1998). Seeing, wanting, owning: The relationship between receptivity to tobacco marketing and smoking susceptibility in young people. Tob Control, 7(2), 123-128. http://dx.doi.org/10.1136/tc.7.2.123

Gall, S., Huynh, Q. L., Magnussen, C. G., Viikari, J. S. A., Kähönen, M., Dwyer, T., ... Venn, A. (2014). Exposure to parental smoking in childhood or adolescence is associated with increased carotid intima-media thickness in young adults: Evidence from the cardiovascular risk in young Finns study and the childhood determinants of adult health study. Eur Heart J. http://dx.doi.org/10.1093/eurheartj/ehu049

Giedd, J. N., Blumenthal, J., Jeffries, N. O., Castellanos, F. X., Liu, H., Zijdenbos A., ... Rapoport, J. L. (1999). Brain development during childhood and adolescence: A longitudinal MRI study. Nat Neurosci, 2(10), 861-863. http://dx.doi.org/10.1038/13158

Gierisch, J. M., Bastian, L. A., Calhoun, P. S., McDuffie, J. R., \& Williams, J. W. Jr. (2010). Comparative effectiveness of smoking cessation treatments for patients with depression: a systematic review and meta-analysis of the evidence.

Glantz, S. A. (2013). FDA should ban menthol as an additive not as an undefined "characterizing flavor." Retrieved July 25, 2014 from https://tobacco.ucsf.edu/fda-should-ban-menthol-additive-not-undefinedcharacterizing-flavor

Goodin, R. E. (1989). The ethics of smoking. Ethics, 99(3), 574-624. http://dx.doi.org/10.1086/293100

Goodman, E., \& Capitman, J. (2000). Depressive Symptoms and Cigarette Smoking Among Teens. Pediatrics, 106(4), $748-755$.

Grant, J. E, Potenza M. N., \& Desai, R. A. (2011). Stealing among high school students: Prevalence and clinical correlates. J Am Acad Phyciatry Law, 39(1), 44-52. http://dx.doi.org/10.1556/JBA.1.2012.4.7

Gilpin, E. A., White, M. M., Messer, K., \& Pierce, J. P. (2007). Receptivity to tobacco advertising and promotions among young adolescents as a predictor of established smoking in young adulthood. Am J Public Health, 97(8), 1489-1495; http://dx.doi.org/ 10.2105/AJPH.2005.070359.

Gilmore, A. B., Branston, J. R., \& Sweanor, D. (2010). The case for OFSMOKE: how tobacco price regulation is needed to promote the health of markets, government revenue and the public. Tob Control, 19, 423e430. http://dx.doi.org/10.1136/tc.2009.034470

Gordon, B., \& Sun, B. (2015). A dynamic model of rational addiction: Evaluating cigarette taxes. Marketing Science, 34(3), 452-470. http://dx.doi.org/10.1287/mksc.2014.0885

Global Youth Tobacco Survey (GYTS). (2009). Fact sheet of Indonesia (Ages 13-15). WHO Regional office for South East Asia. Retrieved July 18, 2014 from http://www.searo.who.int/entity/noncommunicable_diseases/ data/ino_gyts_fs_2009.pdf

Hanewinkel, R., Isensee, B., Sargent, J. D., \& Morgenstern, M. (2010). Cigarette advertising and adolescent smoking. American Journal of Preventive Medicine, 38, 359-366. http://dx.doi.org/10.1016/j.amepre.2009. 12.036

Hatsukami, D. K., Kotlyar, M., Hertsgaard, L. A., Zhang, Y., Carmella, S. G., Jensen, J. A., ... Hect, S. S. (2010). Reduced nicotine content cigarettes: Effects on toxicant exposure, dependence and cessation. Addiction, 105, 343-355. http://dx.doi.org/ 10.1111/j.1360-0443.2009.02780.x

Health Canada. (2014). Summary of result of the youth smoking survey 2012-2013. Health Canada. Retrieved August 18, 2015 from http://www.hc-sc.gc.ca/hc-ps/tobac-tabac/research-recherche/stat/_survey-sondage _2012-2013/result-eng.php

Henriksen, L. (2012). Comprehensive tobacco marketing restrictions: Promotion, packaging, price and place. Tob Control, 21, 147-153. http://dx.doi.org/10.1136/tobaccocontrol-2011-050416

Hoek, J., Hoek-Sims, A., \& Gendall, P. (2013). A qualitative exploration of young adult smokers' responses to novel tobacco warnings. BMC Public Health, 13, 609. http://dx.doi.org/10.1186/1471-2458-13-609 
Hospers, J. (1980). Libertarianism and legal paternalism. J Libert Stud, 4(3), 255-265.

International Agency for Research on Cancer (IARC). (2011). IARC handbook on tobacco control volume 14: Effectiveness of tax and price policies for tobacco control. Lyon: IARC.

Jha, P., Ramasundarahettige, C., Landsman, V., Rostrom, B., Thun, M., Anderson, R. N., .. Peto, R. (2013). 21st-century hazards of smoking and benefits of cessation in the United States. N Engl J Med, 368(4), 341-50. http://dx.doi.org/10.1056/NEJMsa1211128

Jiang, J., Ahn, J., Huang, W. Y., \& Hayes, R. B. (2013). Association of Obesity with cardiovascular disease mortality in the PLCO trial. Prev Med, 57(1), 60-64. http://dx.doi.org/10.1016/j.ypmed.2013.04.014

Johnston, L. D, O'Malley, P. M., Bachman, J. G., \& Schulenberg, J. E. (2013). Monitoring the future national survey results on drug use, 1975-2012 (Volume I, Secondary school students). Ann Arbor: Institute for Social Research, University of Michigan.

Kim, A. E., Nonnemaker, J. M., Loomis, B. R., Baig, A., Hill, E., Holloway, J. W., ... Shafer, P. R. (2012). Influence of Tobacco Displays and Ads on Youth: A Virtual Store Experiment. Pediatrics. http://dx.doi.org/10.1542/peds.2012-0197

Kim, H. C., Cho, K. S., Kwon, S. M., \& Lim, J. Y. (2012). The effect of the increase in tobacco price on adolescent smoking in Korea: Smoking reduction and brand switching. Health and Social Welfare Review, 32(3), 429-460.

Konrad, K., Firk, C., \& Uhlhaas, P. J. (2013). Brain development during adolescence. Dtsch Arztebl Int, 110(25), 425-431. http://dx.doi.org/ 10.3238/arztebl.2013.0425.

Lazev, A. B., Herzog, T. A., \& Brandon, T. H. (1999). Classical conditioning of environmental cues to cigarette smoking. Exp Clin Psychopharm, 7(1), 55-63. http://dx.doi.org/10.1037/1064-1297.7.1.56

Lee, K. J. (2014). Current smoking and secondhand smoke exposure and depression among Korean adolescents: analysis of a national cross-sectional survey. The BMJ Open, 4, e003734. http://dx.doi.org/10.1136/ bmjopen-2013-003734.

Lee, S., Ling, P. M., \& Glantz, S. A. (2012). The vector of the tobacco epidemic: Tobacco industry practices in low and middle-income countries. Cancer Cause Control. http://dx.doi.org/10.1007/s10552-012-9914-0

Lenk, K. M, Toomey, T. L., Shi, Q., Erickson, D. J., \& Forster, J. L. (2014). Do sources of cigarettes among adolescents vary by age over time? $J$ Child Adolesc Subst Abuse, 23(2), 137-143. http://dx.doi.org/10.1080/1067828X.2012.750972

Liu, H., \& Tan, W. (2009). The effect of anti-smoking media campaign on smoking behavior: The California experience. Ann. Econ. Finance, 10(1), 29-47.

Loukola, A., Wedenoja, J., Keskitalo-Vuokko, K., Broms, U., Korhonen, T., Ripatti, S., ... Kaprio, J. (2014). Genome-wide association study on detailed profiles of smoking behavior and nicotine dependence in a twin sample. Mol Psychiatry, 19, 615-624. http://dx.doi.org/10.1038/mp.2013.72

Lovato, C., Watts, A., \& Stead, L. F. (2011). Impact of tobacco advertising and promotion on increasing adolescent smoking behaviours. Cochrane Database Sys Rev. http://dx.doi.org/10.1002/14651858.CD00 3439.pub2

Manson, J. E., Ajani, U. A., Liu, S., Nathan, D. M., \& Hennekens, C. H. (2000). A prospective study of cigarette smoking and the incidence of diabetes mellitus among US male physicians. Am J Med, 109(7), 538-542. http://dx.doi.org/10.1016/S0002-9343(00)00568-4

Mardian, R. (2011). Pengaruh promosi penjualan untuk meningkatkan omzet warung tradisional. Udayana University. Retrieved February 13, 2014 from http://www.pps.unud.ac.id/thesis/pdf_thesis/unud-260-1430 528897-tesis\%20pengaruh\%20promosi\%20penjualan\%20untuk\%20meningkatkan\%20omzet\%20warung\% 20tradisional.pdf

Martini, S., \& Sulistyowati, M. (2005). The Determinants of Smoking Behavior among Teenagers in East Java Province, Indonesia. Retrieved February 6, 2013 from http://siteresources.worldbank.org/HEALTHNU TRITIONANDPOPULATION/Resources/281627-1095698140167/IndonesiaYouthSmokingFinal.pdf

Mendelsohn, C. (2011). Nicotine dependence: why is it so hard to quit? MedicineToday, 12(10), 35-40.

Moreland-Russell, S., Harris, J., Snider, D., Walsh, H., Cyr, J., \& Barnoya, J. (2013). Disparities and menthol marketing: Additional evidence in support of point of sale policies. Int J Environ Res Public Health, 10, 4571-4583. http://dx.doi.org/10.3390/ijerph10104571 
Nairn, A., \& Berthon, P. (2003). Creating the customer: The influence of advertising on consumer market segments - evidence and ethics. J Bus Ethics, 42(1), 83-99. http://dx.doi.org/10.1023/A:1021620825950

National Cancer Institute (NCI). (2008). Tobacco control monograph no. 19: The role of the media in promoting and reducing tobacco use. Bethesda, MD: U.S. Department of Health and Human Services, National Institutes of Health, National Cancer Institute.

Ng, N., Weinehall, L., \& Öhman, A. (2007). If I don't smoke, I'm not a real man'-Indonesian teenage boys' views about smoking. Health Edu Res, 22(6), 794-804. http://dx.doi.org/10.1093/her/cyl104

Nichter, M., Padmawati, S., Danardono, M., Ng, N., Prabandari, Y., \& Nichter, M. (2009). Reading culture from tobacco advertisements in Indonesia. Tob Control, 18, 98-107. http://dx.doi.org/10.1136/tc.2008.025809

Nielsen. (2009). How teens use media: A Nielsen report on the myths and realities of teen media trends. Nielsen. Retrieved September 21, 2014 from http://www.universitycircle.org/downloads/How\%20Teens\%20Use\% 20Media.pdf

Olekalns, N., \& Bardsley, P. (1999). The impact of anti-smoking policies on tobacco consumption in Australia. Health Promot J Austr, 9(3), 202-205.

Oriola, T. A. (2009). Ethical and legal analyses of policy prohibiting tobacco smoking in enclosed public spaces. $J$ Law Med Ethics, 37(4), 828-840. http://dx.doi.org/10.1111/j.1748-720X.2009.00454.x

Parrott, A. C., \& Murphy, R. S. (2012). Explaining the stress-inducing effects of nicotine to cigarette smokers. Hum Psychopharmacol Clin Exp, 27, 150-155. http://dx.doi.org/10.1002/hup.1247

Philpott, D. (2014). Sovereignty, Stanford encyclopedia of philosophy (N. Z. Edward Ed). Retrieved August 20, 2014 from http://plato.stanford.edu/archives/sum2014/entries/sovereignty

Polisi Daerah Istemewa Yogyakarta (Polda DIY). (2013, December 20th). Demi membeli rokok, dua remaja curi kotak infaq. Polda DIY. Retrieved August 5, 2014 from http://jogja.polri.go.id/berita/save_pdf/demi -membeli-rokok-dua-remaja-curi-kotak-infaq.html

Rao, S., Aslam, S. K., Zaheer, S., \& Shafique, K. (2014). Anti-smoking initiatives and current smoking among 19,643 adolescents in South Asia: findings from the Global Youth Tobacco Survey. Harm Reduct J, 11(8). http://dx.doi.org/10.1186/1477-7517-11-8

Saarni, S. E., Pietiläinen, K., Kantonen, S., Rissanen, A., \& Kaprio, J. (2009). Association of smoking in adolescence with abdominal obesity in adulthood: A follow-up study of 5 birth cohorts of finnish twins. Am J Public Health, 99(2), 348-354. http://dx.doi.org/10.2105/AJPH.2007.123851

Scientific Committee on Emerging and Newly Identified Health Risks (SCENIHR). (2010). Addictiveness and Attractiveness of Tobacco Additives. Retrieved July 28, 2014 from http://ec.europa.eu/health/ scientific_committees/emerging/docs/scenihr_o_029.pdf

Statistics Canada (SC). (1996). Youth smoking survey, 1994. Retrieved August 18, 2014 from http://www23. statcan.gc.ca/imdb-bmdi/document/4401_D2_T9_V1-eng.pdf

Scollo, M. M., \& Winstanley, M. H. (2012). Tobacco in Australia: Facts and issues, 4th ed. Melbourne: Cancer Council Victoria. Retrieved August 20, 2014 from http://www.TobaccoInAustralia.org.au

Selyaa, A. S., Dierkera, L. C., Rosea, J. S., Hedekerb, D., Lid, X. T. R., \& Mermelsteinb, R. J. (2013). Time-varying effects of smoking quantity and nicotine dependence on adolescent smoking regularity. Drug Alcohol Depend, 128(3), 230-237. http://dx.doi.org/10.1016/j.drugalcdep.2012.08.026

Semba, R, D., Kalm, L. M., de Pee, S., Ricks, M. O., Sari, M., \& Bloem, M. W. (2007). Paternal smoking is associated increased risk of child malnutrition among poor urban families in Indonesia. Public Health Nutr, 10, 7-15. http://dx.doi.org/10.1136/tc.2007.020875

Semba, R. D., de Pee, S., Sun, K., Best, C. M, Sari, M., \& Bloem, M. W. (2008). Paternal smoking and increased risk of infant and under-5 child mortality in Indonesia. Am J Public Health, 98(10), 1824-1826. http://dx.doi.org/10.2105/AJPH.2007.119289

Shadel, W. G., Tharp-Taylor, S., \& Fryer, C. S. (2008). Exposure to cigarette advertising and adolescents' intentions to smoke: the moderating role of the developing self-concept. $J$ Pediatr Psychol, 33, 751-760. http://dx.doi.org/ 10.1093/jpepsy/jsn025.pmid:18356185

Smith, N. C., \& Cooper-Martin, E. (1997). Ethics and target marketing: The role of product harm and consumer vulnerability. $J$ Mark, 6, 1-20. 
Spanopoulos, D., Britton, J., McNeill, A., Ratchen, E., \& Szatkowski, L. (2013). Tobacco display and brand communication at the point of sale: Implications for adolescent smoking behavior. Tob Control. http://dx.doi.org/10.1136/tobaccocontrol-2012-050765

Steinberg, L. (2009). Should the science of adolescent brain development inform public policy? Am Psychol, 64(8), 739-50. http://dx.doi.org/10.1037/0003-066X.64.8.739

Strausburger, V. C, Jordan, A. B., \& Donnerstein, E. (2010). Health effects of Media on children and adolescents. Pediatrics, 125(4), 756-767. http://dx.doi.org/10.1542/peds.2009-2563

Tandilittin, H., \& Luetge, C. (2013). Civil society and tobacco control in Indonesia: The last resort. The Open Ethics Journal, 7, 11-18. http://dx.doi.org/10.2174/1874761201307010011

Tandilittin, H., \& Luetge, C. (2015). CSR activity of tobacco companies in Indonesia: Is it a genuine social responsibility? Online Journal of Health Ethics, 11(1), 3. http://dx.doi.org/10.18785/ ojhe.1101.03

Tobacco Control Legal Consortium (TCLC). (2006). The verdict is in: findings from United States v. Philip Morris, the hazards of smoking. Retrieved July 15, 2014 from http://publichealthlawcenter.org/sites/default/ files/resources/tclc-verdict-light.pdf

Tempo. (2012, December 14th). Demi Rokok, Siswa SMP Nekat Mencuri. Tempo. Retrieved August 4, 2014 from http://www.tempo.co/read/news/2012/12/14/058448244/Demi-Rokok-Siswa-SMP-Nekat-Mencuri

Vaidya, S. G., Vaidya, J. S., \& Naik, U. D. (1999). Sports sponsorship by cigarette companies influences the adolescent children's mind and helps initiate smoking: results of a national study in India. $J$ Indian Med Assoc, 97, 354-356.

van staveren, I. (2007). Beyond utilitarianism and deontology: Ethics in economics. Review of Political Economy, 19(1), 21-35. http://dx.doi.org/10.1080/09538250601080776

Wakefield, M., Terry-McElrath, Y., Chaloupka, F., Barker, D., Slater, S., Clark, P., ... Giovino, G. A. (2002). Tobacco industry marketing at point of purchase after the 1998 MSA billboard advertising ban. Am J Public Health, 92(6), 937-940. http://dx.doi.org/ 10.2105/AJPH.92.6.937

World Health Organization (WHO). (2008). Guidelines for implementation of Article 13 of the WHO Framework Convention on Tobacco Control (Tobacco advertising, promotion and sponsorship). Retrieved August 8 , 2015 from http://www.who.int/fctc/guidelines/article_13.pdf

World Health Organization (WHO). (2011). WHO report on the global tobacco epidemic, 2011: Warning about the dangers of tobacco. Italy: WHO Press.

World Health Organization (WHO). (2012). Global Adult Tobacco Survey (GATS): Indonesia report 2011. Jakarta: WHO Regional Office for South East Asia.

World Health Organization (WHO). (2013a). WHO report on the global tobacco epidemic, 2013: Enforcing bans on tobacco advertising, promotion, and sponsorship. Geneva: WHO Press.

World Health Organization (WHO). (2013b). World health statistics. Geneva: WHO Press.

World Health Organization (WHO). (2015). WHO report on the global tobacco epidemic, 2015: Raising taxes on tobacco. Geneva: WHO Press.

Windle, M., \& Windle, R. C. (2001). Depressive symptoms and cigarette smoking among middle adolescents: Prospective associations and intrapersonal and interpersonal influences. J Consult Clin Psychol, 69(2), 215-226. http://dx.doi.org/10.1037//0022-006X.69.2.215

Zhang, B., Cohen, J., Ferrence, R., \& Rehn, J. (2006). The impact of tobacco tax cuts on smoking initiation among Canadian young adults. Am J Prev Med, 30(6), 474-479. http://dx.doi.org/10.1016/j.amepre.2006.02.001

\section{Copyrights}

Copyright for this article is retained by the author(s), with first publication rights granted to the journal.

This is an open-access article distributed under the terms and conditions of the Creative Commons Attribution license (http://creativecommons.org/licenses/by/3.0/). 